\title{
Real-Time PCR Detection and Discrimination of the Southern and Common Corn Rust Pathogens Puccinia polysora and Puccinia sorghi
}

Jo Anne Crouch and Les J. Szabo, United States Department of Agriculture-Agricultural Research Service (USDA-ARS), Cereal Disease Laboratory, University of Minnesota, St. Paul 55108

\begin{abstract}
Crouch, J. A., and Szabo, L. J. 2011. Real-time PCR detection and discrimination of the southern and common corn rust pathogens Puccinia polysora and Puccinia sorghi. Plant Dis. 95:624-632.

Over the past several years, southern corn rust (SCR) outbreaks caused by the fungus Puccinia polysora have become increasingly problematic for corn growers in the United States. SCR is currently diagnosed through the visual examination of disease symptoms and pathogen morphology, including pigmentation, size, shape, and location of fruiting structures. However, these characteristics are similar to those produced by the common corn rust fungus $P$. sorghi, confounding accurate visual diagnosis of SCR. Here we report the development of a realtime polymerase chain reaction assay that discriminates between $P$. polysora and $P$. sorghi. Sequences of the rDNA internal transcribed

spacer region were determined for $P$. polysora and $P$. sorghi. 5-Carboxyfluorescein fluorophore-labeled hydrolysis probes that differed at 14 nucleotide positions between the species were developed from these data and used to screen DNA extracted directly from rust-infected corn leaves. Species-specific, reproducible identifications of the pathogens were made from as little as $50 \mathrm{pg}$ of DNA within $30 \mathrm{~min}$, and were reliably performed from both recent collections and herbarium specimens. This assay will be useful for rapid and accurate diagnosis of SCR, and could serve as a tool to monitor the distribution and incidence of the disease in the United States.
\end{abstract}

In recent years, southern rust caused by Puccinia polysora has become an increasingly prevalent disease of corn (Zea mays) in the United States. Southern corn rust (SCR) is an episodic disease in temperate and subtropical growing regions like those found in the United States, with the last serious outbreaks occurring in 19721974, 1979, and $1981(16,27,30,37,39)$. As with earlier disease outbreaks, which coincided with increased double cropping of corn in the southeastern coastal plain and lower Mississippi River valley $(16,44)$, the recent upsurge in SCR incidence also occurs during a time of changing land-use patterns. Corn production acreage has doubled in Mexico since 1989, and quadrupled in southern Florida, Arkansas, Louisiana, and Mississippi (43). This increase in cropping offers a greatly expanded host environment in warm-climate areas that are conducive for the overwintering and early staging of the pathogen at the base of the Puccinia pathway (43). Although increased host availability likely contributes to the recent success of the pathogen, the factors underlying the periodicity of SCR outbreaks have yet to be identified.

Corresponding author: L. J. Szabo,

E-mail: les.szabo@ars.usda.gov

Current address of J. A Crouch: USDA-ARS, Systematic Mycology and Microbiology Laboratory, Beltsville, MD 20705.

* The $\boldsymbol{e}$-Xtra logo stands for "electronic extra" and indicates that one supplementary table and three supplementary figures are available online.

Mention of a trademark name or proprietary product does not constitute a guarantee by the United States Department of Agriculture.

Accepted for publication 5 January 2011.

doi:10.1094/PDIS-10-10-0745

This article is in the public domain and not copyrightable. It may be freely reprinted with customary crediting of the source. The American Phytopathological Society, 2011.
Most of the corn hybrids currently grown in the United States are susceptible to SCR, with the episodic nature of the disease presenting variable selection environments that are unfavorable for maintaining and selecting sources of resistance in breeding lines $(16,17,23,41)$. $P$. polysora pustules are produced in abundance after infecting the exposed leaves and sheaths of susceptible plants, leading to widespread death of the infected corn tissue, severe desiccation of the plant, and early senescence $(35,38)$. Disease severity increases as the plant develops, often resulting in plant death, particularly when infection occurs in late-season plantings (16). Although SCR is primarily a foliar disease, $P$. polysora may also infect sheaths and husk leaves, and stem lodging may also occur as an indirect result of photosynthate loss $(4,35)$. Yield reductions due to SCR may be considerable, with losses of up to 45 to $50 \%$ described from earlier epidemics $(8,33,35)$.

Herbarium collections document the presence of $P$. polysora on corn in the Western hemisphere since at least 1879 but the distinctiveness of SCR and the causal organism were not accurately determined until the mid-20th century (10). The fungus was first described causing disease in stands of eastern gamagrass (Tripsacum dactyloides) in Alabama in 1897 (42) but $P$. polysora on corn hosts was misidentified as the common corn rust fungus, $P$. sorghi (20), for several decades after the species was named (10). In 1940, E. C. Stakman collected a corn rust sample from Peru that possessed morphological characteristics that were markedly different from those of P. sorghi, and Cummins made the connection between this "new" corn rust and $P$. polysora (10). Subsequent reexamination of corn rust samples previously diagnosed as $P$. sorghi revealed numerous collections as $P$. polysora, and documented a geographic range that today spans Central and South America, Asia, Africa, and North America $(6,8,10,12,14,33,36)$. In the United States, the fungus is primarily distributed across the lower Mississippi River valley and southeastern coastal plain but has been reported as far north as Wisconsin, Illinois, Pennsylvania, and Indiana and as far west as Kansas, Texas, and Oklahoma $(7,14,32,37,39,43)$.

Despite the morphological distinctiveness of $P$. polysora and $P$. sorghi, the differences between the two diseases and their causal 
organisms may be subtle or even impossible to detect. Microscopic examination of teliospores, if present, will quickly distinguish the two pathogens (Fig. 1D-F, I, and J; 10,11) but evaluation of other morphological structures and phenotypic indicators may yield unreliable diagnoses. Misdiagnosis of SCR is not uncommon, especially during early stages of disease development, because teliospores are generally produced late in the season or not at all (24), and sometimes the telial sori do not dehisce and remain covered with the epidermis, making them difficult to locate (Fig. 1A; 4). Aside from teliospore morphology, the distribution of uredinial sori is one of the best available diagnostic features. P. polysora pustules primarily develop on the upper leaf surface, whereas $P$. sorghi pustules develop on both the upper and lower leaf surfaces; however, $P$. polysora is technically amphigynous, and the occurrence of intermediate forms may confound accurate identification (29). Microscopic examination of urediniospores alone is not always a reliable indicator, because these spores may be similar in size and shape, and germ-pore distribution for both $P$. polysora and $P$. sorghi is equatorial and of overlapping number (Fig. 1B, C, and K; 12). In the field, the coloration of uredinial sori may be an informative diagnostic character, with $P$. polysora pustules appearing orange to tan and $P$. sorghi pustules appearing dark red to brown; however, the subjectivity of this assessment may lead to erroneous diagnosis of SCR. Another variable trait between the two corn rusts is the appearance of the host epidermal layer covering the sori. $P$. polysora sori tend to remain covered by the host epidermis, with only a longitudinal slit forming at dehiscence (Fig. 1A; 4), whereas $P$. sorghi more commonly ruptures and shreds the epidermal layer (Fig. $1 \mathrm{G}$ and $\mathrm{H}$; 4). This characteristic may not consistently provide accurate identification, because the $P$. polysora epidermal layer may be ruptured or flake away due to me- chanical injury (29). In short, unless teliospores are present on the diseased corn plant and can be examined microscopically, the use of morphology and phenotypic assessments may not provide errorproof diagnosis of SCR.

Accurate identification of SCR caused by $P$. polysora is of fundamental importance to scientists monitoring the distribution and incidence of this disease, and for plant health practitioners who need to provide timely, accurate, and cost-effective disease management recommendations to corn growers. As noted by Rodriguez-Ardon and colleagues 30 years ago, there are many differences between $P$. polysora and $P$. sorghi but, ultimately, SCR caused by $P$. polysora can kill the plant, whereas common corn rust caused by $P$. sorghi rarely does (35). Therefore, our objective in the present work was to develop a molecular diagnostic assay capable of routinely discriminating between $P$. polysora and $P$. sorghi in a definitive manner, using technology readily available in plant disease diagnostic laboratories. Neither $P$. polysora and $P$. sorghi have been characterized on the molecular level; however, previous studies have shown that the sequence variation present in the internal transcribed spacer (ITS) region of the nuclear rRNA provides a reliable template for real-time polymerase chain reaction (PCR) detection of rust fungal species $(2,3,15,18,22,31)$. Here, we report the development of a real-time PCR assay using species-specific fluorogenic ITS1 hydrolysis probes capable of quickly and accurately discriminating between $P$. polysora and $P$. sorghi.

\section{Materials and Methods}

Fungal isolates, DNA manipulations, and sequence analysis. A summary of the Puccinia samples used in this study is provided in Table 1. Samples were examined microscopically to evaluate sori, urediniospores, and teliospores, then compared with published
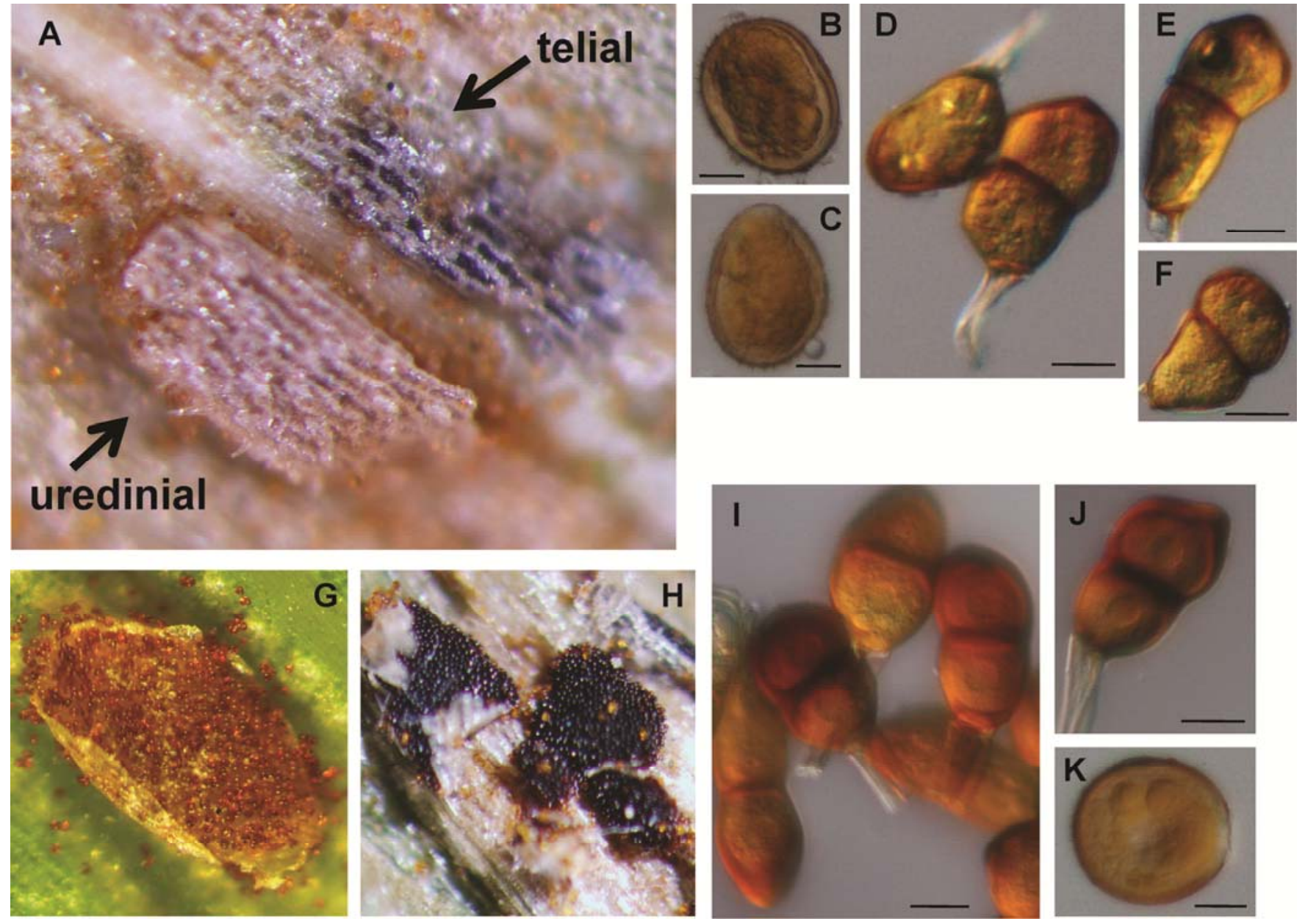

Fig. 1. Morphology of two corn rust fungi. A-F, Puccinia polysora: A, telial and uredinial sori; $\mathbf{B}$ and $\mathbf{C}$, urediniospores; D-F, teliospores. G-K, P. sorghi: G, uredinial sorus; H, telial sorus; I and $\mathbf{J}$, teliospores; $\mathbf{K}$, urediniospore. Bar $=10 \mu \mathrm{m}$. 
Table 1. Puccinia samples included in the study

\begin{tabular}{|c|c|c|c|c|}
\hline Sample ${ }^{a}$ & Host & Collection site ${ }^{b}$ & Year & Collector \\
\hline \multicolumn{5}{|l|}{ Puccinia polysora } \\
\hline BPI0878058 & Zea mays & Nigeria & 2006 & M. C. Aime \\
\hline BPI0878059 & Z. mays & South Africa & 2006 & M. C. Aime \\
\hline BPI093792 & Z. mays & Lafayette, LA & 1888 & A. B. Langlois \\
\hline BPI093805 & Z. mays & Sanford, FL & 1924 & A. C. Foster \\
\hline BPI093808 & Z. mays & El Salvador & 1943 & F. L. Wellman \\
\hline BPI093810 & Z. mays & Quincy, FL & 1943 & A. S. Rhoads \\
\hline BPI093811 & Z. mays & El Salvador & 1943 & F. L. Wellman \\
\hline BPI093812 & Z. mays & Costa Rica & 1923 & F. L. Stevens \\
\hline BPI093818 & Z. mays & Nicaragua & 1956 & A. Salazar \\
\hline BPI093820 & Z. mays & Venezuela & 1957 & G. Malaguti \\
\hline BPI093821A & Z. mays & Peru & 1940 & E. C. Stakman \\
\hline BPI093822 & Z. mays & Nicaragua & 1952 & S. C. Litzenberger \\
\hline BPI093823 & Z. mays & Malaysia & 1955 & R. H. Forster \\
\hline BPI093824 & Z. mays & Nicaragua & 1956 & A. Salazar \\
\hline BPI093825 & Z. mays & Nicaragua & 1957 & S. C. Litzenberger \\
\hline BPI093826 & Z. mays & Marshall, TX & 1957 & J. C. Frobese \\
\hline BPI093827 & Z. mays & Cambodia & 1961 & S. C. Litzenberger \\
\hline BPI093828c & Z. mays & Nicaragua & 1952 & S. C. Litzenberger \\
\hline BPI093829c & Z. mays & Cambodia & 1959 & S. C. Litzenberger \\
\hline BPI093830 & Z. mays & Philippines & 1955 & A. M. Brunson \\
\hline BPI093846 & Z. mays & Venezuela & 1957 & A. L. Robert \\
\hline BPI093847 & Z. mays & Kenya & 1956 & W. H. Storey \\
\hline BPI093848 & Z. mays & Millen, GA & 1948 & A. G. Johnson \\
\hline BPI093849 & Z. mays & Columbia & 1957 & R. L. Sikes \\
\hline BPI093850 & Z. mays & Nicaragua & 1952 & S. C. Litzenberger \\
\hline BPI093851 & Z. mays & Kenya & 1956 & L. S. Storey \\
\hline G10-779 & Z. mays & Lonoke Co., AR & 2010 & W. S. Monfort \\
\hline G10-780 & Z. mays & Decatur Co., GA & 2010 & R. C. Kemerait \\
\hline G10-787 & Z. mays & Macon Co., GA & 2010 & R. C. Kemerait \\
\hline G10-788 & Z. mays & Macon Co., GA & 2010 & R. C. Kemerait \\
\hline G10-789 & Z. mays & Macon Co., GA & 2010 & R. C. Kemerait \\
\hline G10-790 & Z. mays & Macon Co., GA & 2010 & R. C. Kemerait \\
\hline G10-791 & Z. mays & Seminole Co., GA & 2010 & R. C. Kemerait \\
\hline G10-803 & Z. mays & Macon Co., GA & 2010 & R. C. Kemerait \\
\hline G10-804 & Z. mays & Macon Co., GA & 2010 & R. C. Kemerait \\
\hline G10-861 & Z. mays & Caldwell Co., KY & 2010 & D. E. Hershman \\
\hline G10-862 & Z. mays & Caldwell Co., KY & 2010 & D. E. Hershman \\
\hline G10-927 & Z. mays & Bureau Co., IL & 2010 & C. A. Bradley \\
\hline HSZ0253a & Z. mays & $\mathrm{HI}$ & 2000 & S. H. Hulbert \\
\hline HSZ1878 (PP-C1) & Z. mays & KY & 2009 & P. Vincelli \\
\hline HSZ1879 (PP-C2) & Z. mays & KY & 2009 & P. Vincelli \\
\hline MIN495555d & Z. mays & Marietta, GA & 1920 & E. Bartholomew \\
\hline PP-1-BB & Z. mays & KY & 2009 & P. Vincelli \\
\hline PP1-X & Z. mays & KY & 2009 & P. Vincelli \\
\hline \multicolumn{5}{|l|}{ P. sorghi } \\
\hline G10-928e & Z. mays & Christian Co., IL & 2010 & C. A. Bradley \\
\hline G10-929e & Z. mays & White Side Co., IL & 2010 & C. A. Bradley \\
\hline G10-930 & Z. mays & Champaign Co., IL & 2010 & C. A. Bradley \\
\hline HI1 (HSZ0253b) ${ }^{\mathrm{f}}$ & Z. mays & Molokai, HI & 1989 & S. Hulbert \\
\hline HSZ1661 & Z. mays & Ethiopia & 2007 & A. P. Roelfs \\
\hline HSZ1993 & Z. mays & Orrock Twp., MN & 2010 & J. L. Johnson \\
\hline HSZ1994 & Z. mays & St. Paul, MN & 2010 & B. J. Elliott \\
\hline MIN466439 & Z. mays & St. Louis Co., MN & 1923 & H. C. Gilbert \\
\hline MIN484449 & Z. mays & St. Paul, MN & 1916 & M. N. Levine \\
\hline MIN495569 & Z. mays & Jackson, TN & 1917 & E. C. Stakman \\
\hline MIN495571 & Z. mays & Brookings, SD & 1892 & D. Griffiths \\
\hline MN1 & Z. mays & Roseville, MN & 2010 & J. A. Crouch \\
\hline MN2 & Z. mays & White Bear Lake, MN & 2010 & J. A. Crouch \\
\hline \multicolumn{5}{|l|}{ Other Puccinia spp. } \\
\hline P. andropogonis HSZ0027 & Andropogon geradii & Burnett Co., WI & 1998 & A. P. Roelfs \\
\hline P. graminis 06Ken $19-\mathrm{V}-3$ & Triticum aestivum & Kenya & 2006 & Y. Jin \\
\hline P. virgata $\mathrm{HSZ} 1903$ & Sorghastrum nutans & Steuben Co., NY & 2009 & G. C. Bergstrom \\
\hline
\end{tabular}

a Samples with the prefixes MIN, BPI, and HSZ are stored in the permanent collections of the following herbariums and collections: MIN = Bell Herbarium, University of Minnesota, St. Paul; BPI = United States National Fungus Collection, Beltsville, MD; and HSZ = Cereal Disease Laboratory collection, St. Paul, MN. HSZ samples are stored at $-20^{\circ} \mathrm{C}$ in the presence of desiccant. DNA from samples with the prefix "G10" was extracted at the University of Florida Plant Disease Clinic, Gainesville; all other samples were extracted at the Cereal Disease Laboratory, St. Paul, MN. Unless otherwise noted, samples used for DNA extractions consisted of rust fungus infected leaf tissue.

b Unless otherwise noted, samples are from the United States.

c Specimen also contained hyperparasite fungus Spaerellopsis filum.

d Although curated as Puccinia sorghi, real-time polymerase chain reaction (PCR) and morphological examinations identified this specimen as $P$. polysora.

e Submitted as $P$. polysora; real-time PCR identified this specimen as $P$. polysora.

f Sample consisted of purified urediniospores. 
descriptions of $P$. polysora and $P$. sorghi (12) for species determination. Low-magnification examinations were performed using an Olympus SZXIZ dissecting scope with photos generated using the NIS Elements F software; a Nikon H600L microscope equipped with NIS Elements AR3.1 software was used for $\times 400$ imaging.

Genomic DNA was purified from infected leaf tissue using the Omni-Pure Genomic DNA Extraction Kit (G-Biosciences, St. Louis) according to previously described protocols (1); 15 DNA samples were provided by the University of Florida Plant Disease Clinic (Table 1). The ITS region of the nuclear rDNA was PCR amplified using the primer pair ITS1F/RUST1 as described (1). After column purification using the Wizard SV Gel and PCR Clean-up kit (Promega Corp., Madison, WI), amplicons were cloned and sequenced as described (1). Six separate clones were sequenced in both directions per sample. Sequences were assembled using Sequencher v4.6 (Ann Arbor, MI). Sequences have been deposited with the National Center for Biotechnology Information (NCBI) GenBank (HQ189432 to HQ189433). Sequence alignments were performed using Clustal W2 (40) on the EBI-EMBL server (http://www.ebi.ac.uk/Tools/clustalw2/index.html); BoxShade 3.21 was used to color the alignment (http://www.ch. embnet.org/software/BOX_form.html).

Real-time PCR. Real-time PCR probes and primers were designed based on the aligned ITS sequence data using Primer3 (http://frodo.wi.mit.edu/primer3/) and synthesized by IDT (Coralville, IA). Final primer and probe sequences used for real-time PCR analyses are summarized in Table 2. Additional primers were tested in various combinations with the final set of primers and probes but were not used due to the production of lower fluorescence levels; these sequences are as provided in Supplementary Table S1. Probes were labeled with a 5-carboxyfluorescein fluorophore (FAM) reporter dye on the $5^{\prime}$ end and two quenchers: Iowa Black on the $3^{\prime}$ end and an internal ZEN. For real-time PCR experiments, DNA extracts from the Omni-Pure preparations were diluted 1:50, DNA extracts provided by University of Florida were performed from undiluted stock, and DNA stocks extracted from purified urediniospores were normalized to $15 \mathrm{ng} / \mu \mathrm{l}$ after quantification with a Nano-Drop 1000 spectrophotometer (Thermo Scientific, Wilmington, DE). Experiments were either performed in a Cepheid SmartCycler (Cepheid, Sunnyvale, CA) or a Roche Light Cycler 480 II (Roche Applied Science, Indianapolis, IN) using the following cycling program: $95^{\circ} \mathrm{C}$ for $120 \mathrm{~s}$, followed by 45 cycles of $95^{\circ} \mathrm{C}$ for $5 \mathrm{~s}, 60^{\circ} \mathrm{C}$ of annealing for $30 \mathrm{~s}$, and $72^{\circ} \mathrm{C}$ of extension for $1 \mathrm{~s}$. Cepheid SmartCycler reactions consisted of 2.0 $\mu \mathrm{l}$ of DNA, $1.25 \mu \mathrm{l}$ of each primer $(20 \mu \mathrm{M}$ stocks $), 2.5 \mu \mathrm{l}$ of probe (20 $\mu \mathrm{M}$ stocks), and the equivalent of $1 / 2$ OmniMix HS PCR Master Mix bead (Takara Bio Inc., Shiga, Japan) to a final volume of $20 \mu \mathrm{l}$ using sterile $\mathrm{dH}_{2} \mathrm{O}$ (Water-Ultra-Pure, molecular-biology grade; Quality Biological Inc., Gaithersburg, MD). SmartCycler reaction thresholds were manually set to 30 fluorescence units. Roche Light Cycler reactions consisted of 20- $\mu$ l volumes containing $2 \mu \mathrm{l}$ of sample DNA, $10 \mu \mathrm{l}$ of Roche Light Cycler 480 Probes Master Mix, PCR-grade sterile $\mathrm{dH}_{2} \mathrm{O}$ provided with the master mix, $1.25 \mu \mathrm{l}$ of each primer $(20 \mu \mathrm{M}$ stocks $)$, and $2.5 \mu \mathrm{l}$ of probe $(20$ $\mu \mathrm{M}$ stocks). Roche Light Cycler reaction thresholds were calculated automatically by setting the noise band at default settings (noise band $=2.23$, standard multiplier $=12$ ) or through analysis of

Table 2. Polymerase chain reaction primers and fluorescent-labeled probes used in this study ${ }^{\mathrm{a}}$

\begin{tabular}{ll}
\hline Primer/probe name & \multicolumn{1}{c}{ Sequence } \\
\hline PpolF & CCAAGAGGTACACCTGTTTGAGT \\
PpolR & CATTATTACACATCAAGTCAATCCA \\
PsorF & CCAAAAGGCACACCTGTTTGAGT \\
PsorR & AATTATTACACATCAAGTCAATCCA \\
PPOLY & fam-TGCAACAAA-zen-GTTATATTCAGGAAAAGAA-IAblk-fq \\
PSORG & fam-TGCTATATA-zen-AAGAAGATGACTTATACAT- $I A b l k-f q$ \\
\hline
\end{tabular}

${ }^{a}$ Modifications to probes are shown in italics; fam = 5-carboxyfluorescein fluorophore, IAblk-fq = Iowa Black quencher, and zen =internal ZEN quencher.

\section{Puccinia polysora Puccinia sorghi}

\section{Puccinia polysora Puccinia sorghi}

\section{Puccinia polysora Puccinia sorghi}

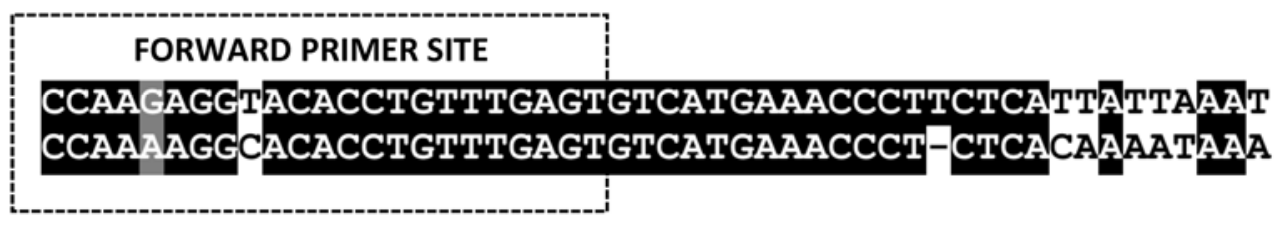

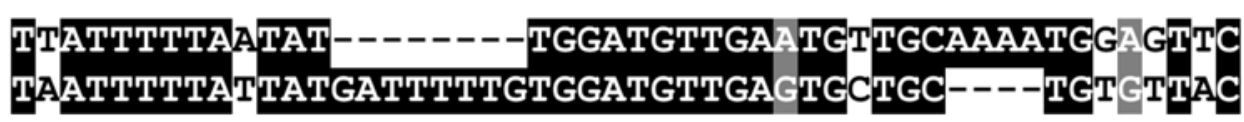

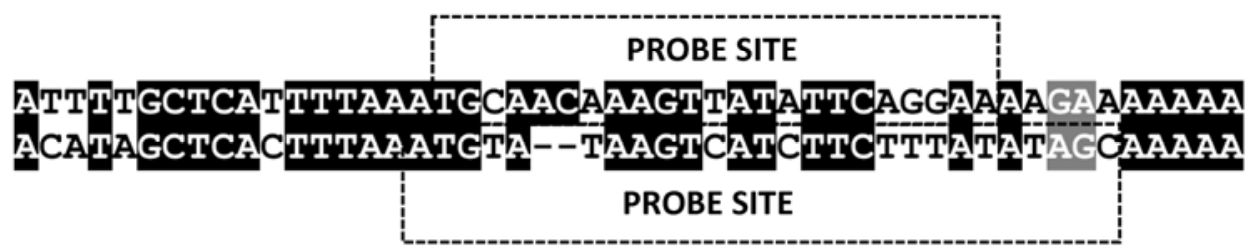

Puccinia polysora Puccinia sorghi

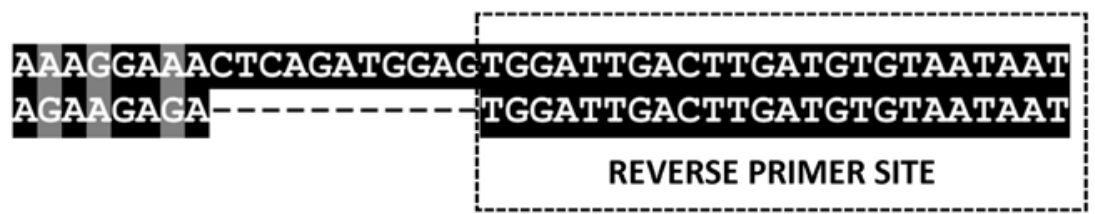

Fig. 2. DNA sequence alignment of the internal transcribed spacer-1 region from Puccinia polysora and $P$. sorghi showing the polymerase chain reaction amplicons, and positions of primer and probe binding sites. 
the second derivative using the Light Cycler software (release 1.5.0 $\mathrm{SP} 3$ ). All reactions were performed for a minimum of two replicates and, in some cases, reactions were repeated a third time. Positive reactions were those that reached the threshold value prior to cycle 40. Water blanks and samples of non-target Puccinia spp. (Table 1) were included as negative controls. After cycling, amplification was confirmed for all samples by agarose gel electrophoresis.

Standard curves were generated using both the SmartCycler and Roche equipment and chemistry by performing simultaneous realtime PCR reactions from two 10 -fold dilution series from purified urediniospore DNA of $P$. polysora HSZ0253a (50 pg to $100 \mathrm{ng}$ ) and $P$. sorghi $\mathrm{HI} 1$ (50 pg to $100 \mathrm{ng}$ ).

\section{Results}

Determination of representative corn rust ITS sequences and design of the real-time PCR assay. The rDNA ITS region has been previously shown as an effective marker for use in real-time PCR discrimination and detection of known rust fungal species $(2,3,15,18,22,31)$; therefore, this sequence was targeted as the basis of our corn rust assay. Publicly available $P$. polysora and $P$. sorghi ITS sequences from NCBI GenBank (http://ncbi.nlm.nih.gov/) were first evaluated to determine whether suitable exemplar sequences were available to serve as templates for assay design. At the time this study was initiated, a single $P$. polysora ITS sequence from Thailand was curated by GenBank (AB536715); however, the sequence could not be verified, because the data were not associated with voucher specimens or a publication. Therefore, fresh collections of $P$. polysora were obtained to generate ITS sequence data for this species. Two samples of corn rust fungi, designated HSZ1878 and HSZ1879, were field identified as $P$. polysora causing SCR in 2009 (courtesy of P. Vincelli, University of Kentucky). Visual examination of morphological features-especially the shape of the telia-identified these samples as $P$. polysora, consistent with published descriptions (Fig. 1A-F; 10,12,29). Sequences of the ITS region derived from the 1,330-bp amplicon generated from primers ITS1/RUST1 from $P$. polysora HSZ1878 and HSZ1879 were identical to one another. Nucleotide queries using BLASTn searches of the GenBank database (http://blast.ncbi.nlm. nih.gov/Blast.cgi) showed that these sequences shared $99 \%$ identity with GenBank Thailand accession AB536715 labeled as $P$. polysora.

For development of the $P$. sorghi template, two ITS sequences from P. sorghi were identified from GenBank. P. sorghi AY114291 was a directly deposited, unpublished sequence produced from isolate HI1 (L. J. Szabo, unpublished data). HI1 is a single-pustule purified strain of $P$. sorghi that has been well studied and experimentally documented as the causal agent of common corn rust (21), and a sample of the strain was already present in our laboratory. The HI1 sequence shared $99 \%$ nucleotide identity with the second curated ITS sequence of $P$. sorghi, DQ345724, which was reported as the causal agent of common corn rust in Oman in 2006 (13). On this basis, we selected the ITS sequence of HI1 as the template sequence for the $P$. sorghi probe design.

Comparison of the ITS sequences of $P$. polysora HSZ1878 and $P$. sorghi HI1 showed that there were 82 nucleotide indels between the two sequences, and $15 \%$ of the aligned nucleotide positions differed between the two fungi. Within the ITS1 region, a 28-bp sequence was identified with only $50 \%$ identity between the species; this region was used as the basis of probe design (Fig. 2), with the PPOLY probe designed to the $P$. polysora template sequence and the PSORG probe designed to $P$. sorghi template sequence. Four sets of PCR primers flanking the probe region were designed and tested (data not shown) but it was observed that primer pairs PpolF/R and PsorF/R, positioned at the same site within the sequence (Fig. 2), consistently produced amplicons that led to reliable fluorescence; therefore, we used these primer pairs for all subsequent reactions. Primer and probe sequences used for the detection assays are summarized in Table 2; unused primer sequences are provided in Supplementary Table S1. Primer pair
PpolF/R, designed from $P$. polysora, differed from the PsorF/R primer pair designed from $P$. sorghi by two transitions in the forward primer and a single transversion in the reverse primer. When used to screen the population of corn rust fungi, $\mathrm{PpolF} / \mathrm{R}$ and PsorF/R produced PCR amplicons from both $P$. polysora and $P$. sorghi, as well as from DNA samples of $P$. andropogonis, $P$. graminis, and $P$. virgata extracted from other warm-season grass hosts; therefore, these primers were not species specific. Preliminary experiments showed that either of these two primer pairs could be paired with either of the two probes and provide accurate, species-specific real-time PCR detection; however, an increase in fluorescence levels was observed when reactions were performed using the $\mathrm{PpolF} / \mathrm{R}$ primers in combination with the $P$. polysoraspecific PPOLY probe and the PsorF/R primers in combination with the $P$. sorghi-specific PSORG probe. For example, use of the PsorF/R primer pair with the PSORG probe increased fluorescence levels by approximately 20 to 30 units relative to the use of PpolF/R with PSORG when performed with the Cepheid Smart Cycler (data not shown). Thus, although the power of the real-time PCR reactions for discrimination of the two corn rust fungi was based on specific binding of the probe, all subsequent reactions made use of the PpolF/R and PsorF/R primers in combination with the appropriate species-specific probe to take advantage of the observed increase in fluorescence produced by these primers.

Assay sensitivity. Two 10-fold serial dilution series of purified fungal genomic DNA were performed to evaluate the sensitivity of the assay using both the SmartCycler and Roche Light Cycler equipment. A summary of the standard curves for the $P$. polysoraspecific PPOLY probe and the P. sorghi-specific PSORG probe and associated data is provided in Supplementary Figure S1. For both probes, as little as $50 \mathrm{pg}$ of template DNA resulted in positive reactions in a reproducible manner. Lower concentrations $(5 \mathrm{pg})$ also produced late-cycle positives for both probes but thresholds were only exceeded after cycle 42 ; therefore, these data were not included in standard curves. Standard curves were linear over five orders of magnitude for both dilution series for both assays, ranging from $50 \mathrm{pg}$ to $100 \mathrm{ng}$, with $r^{2}$ values $\geq 0.97$.

Application and assessment of the real-time PCR assay. The ITS1-based FAM-labeled real-time PCR hydrolysis probes specific for $P$. polysora and P. sorghi were first tested by screening 57 corn rust samples (Table 1) using a Roche LightCycler 480, including both recently collected samples and older specimens from herbaria originally collected between 1888 and 2006. The results of these experiments are shown in Figure 3 and Supplementary Figure S2. When used to evaluate recently collected corn rust samples (collected after 2000), real-time PCR assays using the PPOLY probe produced positive results for all but two $P$. polysora samples and negative results for $P$. sorghi samples and negative controls $(<2$ fluorescence units observed). Assays using the PSORG probe reactions produced positive results for the recently collected $P$. sorghi samples (collected after 1989) and negative reactions from all $P$. polysora samples and negative controls. Non-target DNA samples of $P$. andropogonis, $P$. graminis, and $P$. virgata produced negative results for both probes. Visualization of the PCR amplification products showed that all 60 rust samples produced the expected 181- to 186-bp amplicon using both PCR primer pairs (data not shown).

Two samples submitted as $P$. polysora, G10-928 and G10-929, were identified as $P$. sorghi using the real-time assay, with negative results generated through analysis with the PPOLY probe and positive results generated through analysis with the PSORG probe. Because we only possessed DNA extractions in our laboratory and did not have the original biological materials from these samples, we could not inspect the morphology of the fungi to substantiate or refute the molecular diagnosis.

DNA extracted from herbarium samples of corn rust was accurately discriminated according to species using the PPOLY/ PSORG probes, although cycle threshold $\left(\mathrm{C}_{\mathrm{T}}\right)$ values were generally greater than what was observed from freshly collected samples and, in some instances, produced lower maximum fluorescence 
levels (Fig. 3; Supplementary Figure S2). All but 4 of the $26 P$. polysora herbarium specimens were confirmed as $P$. polysora through the real-time PCR assay, with the observed fluorescence levels well above the threshold (Fig. 4; Supplementary Figure S2). Examination of these four $P$. polysora samples (BPI093811, BPI093820, BPI093830, and BPI093846, collected between 1943 and 1957 from the Philippines, Venezuela, and El Salvador) using the PSORG probe also did not identify these samples as P. sorghi. DNA quantities for these four samples were comparable with DNA quantities obtained from samples that yielded positive fluorescence levels (107 to $1,063 \mathrm{ng} / \mu \mathrm{l}$; absorbance ratio of 260 to $280 \mathrm{~nm}>$ 1.90); although, because DNA extractions were made directly from
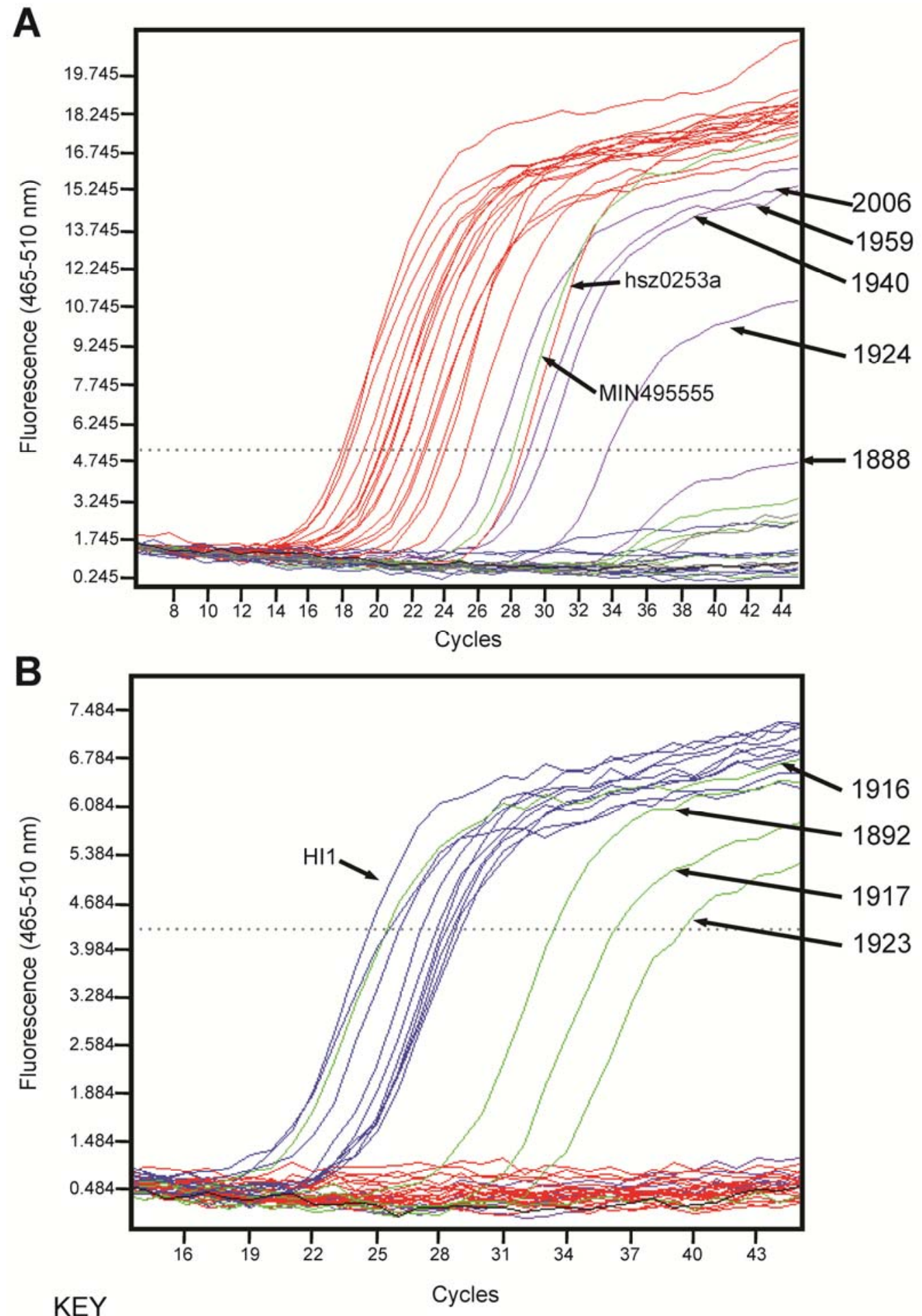

KEY

Cycles

\section{P. polysora \\ $P$. polysora herbarium}

Negative

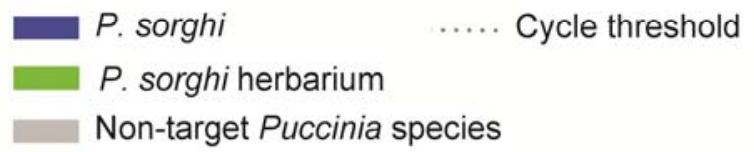

Fig. 3. Real-time polymerase chain reaction analysis of corn rust fungal samples using species-specific assays. A, Puccinia polysora; $\mathbf{B}, P$. sorghi. Analysis was performed using a Roche Light Cycler 480. Samples used to generate standard curves (Supplementary Figure S1; P. polysora = HSZ0253a, P. sorghi $=$ HI1) and discussed in the text are marked. Dates for selected herbarium specimens are shown to the right of the graphs. 


\begin{tabular}{|c|c|c|}
\hline SPECIES & SAMPLE ID & 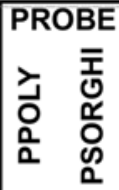 \\
\hline Puccinia polysora & BPI0878058 & \\
\hline Puccinia polysora & BPI0878059 & \\
\hline Puccinia polysora & BPI093792 & \\
\hline Puccinia polysora & BPI093805 & \\
\hline Puccinia polysora & BPI093808 & \\
\hline Puccinia polysora & BPI093810 & \\
\hline Puccinia polysora & BPI093811 & \\
\hline Puccinia polysora & BPI093812 & \\
\hline Puccinia polysora & BPI093818 & \\
\hline Puccinia polysora & BPI093820 ${ }^{1}$ & \\
\hline Puccinia polysora & BPI093821A & \\
\hline Puccinia polysora & BPI093822 & \\
\hline Puccinia polysora & BPI093823 & \\
\hline Puccinia polysora & BPI093824 & \\
\hline Puccinia polysora & BPI093825 & \\
\hline Puccinia polysora & BPI093826 & \\
\hline Puccinia polysora & BPI093827 & \\
\hline Puccinia polysora & BPI093828 & \\
\hline Puccinia polysora & BPI093829 & \\
\hline Puccinia polysora & BPI093830 & \\
\hline Puccinia polysora & BPI093846 & \\
\hline Puccinia polysora & BPI093847 & \\
\hline Puccinia polysora & BPI093848 & \\
\hline Puccinia polysora & BPI093849 & \\
\hline Puccinia polysora & BPI093850 & \\
\hline Puccinia polysora & BPI093851 & \\
\hline Puccinia polysora & G10-779 & \\
\hline Puccinia polysora & G10-780 & \\
\hline Puccinia polysora & G10-787 & \\
\hline Puccinia polysora & G10-788 & \\
\hline Puccinia polysora & G10-789 & \\
\hline Puccinia polysora & G10-790 & \\
\hline Puccinia polysora & G10-791 & \\
\hline Puccinia polysora & G10-803 & \\
\hline Puccinia polysora & G10-804 & \\
\hline Puccinia polysora & G10-861 & \\
\hline Puccinia polysora & G10-862 & \\
\hline Puccinia polysora & G10-927 & \\
\hline Puccinia polysora & HSZ0253a & \\
\hline Puccinia polysora & HSZ1878 (PP-C1) & \\
\hline Puccinia polysora & HSZ1879 (PP-C2) & \\
\hline Puccinia polysora & MIN495555 & \\
\hline Puccinia polysora & PP-1-BB & \\
\hline Puccinia polysora & PP1-X & \\
\hline Puccinia sorghi & G10-928 & \\
\hline Puccinia sorghi & G10-929 3 & \\
\hline Puccinia sorghi & G10-930 & \\
\hline Puccinia sorghi & HI1 (HSZ0253b) & \\
\hline Puccinia sorghi & HSZ1661 & \\
\hline Puccinia sorghi & HSZ1993 & \\
\hline Puccinia sorghi & HSZ1994 & \\
\hline Puccinia sorghi & MIN466439 & \\
\hline Puccinia sorghi & MIN484449 & \\
\hline Puccinia sorghi & MIN495569 & \\
\hline Puccinia sorghi & MIN495571 & \\
\hline Puccinia sorghi & MN1 & \\
\hline Puccinia sorghi & MN2 & \\
\hline Puccinia graminis & 06Ken19-V-3 & \\
\hline Puccinia andropogonis & HSZO027 & \\
\hline Puccinia virgata & HSZ1903 & \\
\hline Sterile water & & \\
\hline
\end{tabular}

Fig. 4. Summary data matrix showing the results of the real-time polymerase chain reaction analysis of corn rust fungi using the PPOLY and PSORG probes designed for detection of Puccinia polysora and $P$. sorghi, respectively. The matrix is based on the analyses performed using the Roche LightCycler $480 \mathrm{II}$. Filled black boxes indicate that all replicates were positive, gray boxes indicate that replicates resulted in both positive and negative results, and white boxes indicate that all replicates were negative. Data presented in the matrix are based on the consensus of two or more replicate runs. infected leaf tissue, it could not be determined how much rust fungal DNA was present in these samples relative to plant DNA. Assessment of DNA quality through $1.0 \%$ agarose gel analysis showed the DNA of these four samples to be similar to the DNA from samples for which species-specific detection was performed (data not shown). Agarose gel visualization of the PCR product from the PPOLY and PSORG assays for the four negative samples showed that amplicons were produced for all four of the reactions, although bands were much fainter than those observed from other samples. Morphological structures of these four P. polysora samples were consistent with the species determination for these specimens, with uredinial sori distributed on the upper leaf surface and covered with the plant epidermal layer; no telia were present (data not shown). Two of these four $P$. polysora sample specimens (BPI093820 and BPI093830) may have contained lower levels of rust fungal DNA, because the sori were occupied by the pycnidia of the rust hyperparasite Sphaerellopsis filum, and few urediniospores remained in these sori. Together, these data suggested that the real-time PCR detection failures of the four P. polysora herbarium specimens was possibly based on the failure of the probe to bind efficiently to the target region, although we could not exclude the possibility that the decreased production of amplicon resulted in reduced fluorescence relative to the other samples. Investigations of molecular variation in historical samples of $P$. polysora populations from geographic regions outside the United States and non-corn host plants that might account for these detection failures are ongoing, and will be addressed in a future publication.

From the $P$. sorghi herbarium specimens screened using the PSORG probe, three of the four PSORG-positive samples exceeded the threshold between cycles 26.89 and 33.63, while all other $P$. sorghi samples exceeded the threshold between cycles 24.33 and 27.68. P. sorghi samples MIN495571 and MIN484449, collected in the years 1892 and 1916, respectively, produced fluorescence levels that were equal to or greater than fluorescence observed from samples of the fungus collected in 2010, while other P. sorghi herbarium samples produced curves that leveled off between approximately 5 and 5.5 fluorescence units (Fig. 3). Herbarium specimen MIN495555, curated as $P$. sorghi, was identified as $P$. polysora using the PPOLY and PSORG assays, with the PPOLY fluorescence curves produced by this sample on par with curves produced by modern samples of $P$. polysora $\left(\mathrm{C}_{\mathrm{T}}=27.28\right.$; Supplementary Figure S2). Subsequent microscopic examination of MIN495555 confirmed the molecular identification of the specimen as $P$. polysora, with telial and uredinial sori largely distributed on the upper leaf surface and covered with the plant epidermal layer, and telia distinctively shaped in the P. polysora type (data not shown).

Use of the PPOLY and PSORG real-time assays on the Cepheid SmartCycler. Because we anticipated that one potential application of this assay would be the discrimination of corn rust fungi by laboratories in the U.S. National Plant Diagnostic Network, we selected a subset of the $P$. polysora and $P$. sorghi samples and analyzed them with the PPOLY and PSORG probes on the Cepheid SmartCycler real-time PCR equipment. This equipment is routinely employed in molecular plant disease diagnostic laboratories; therefore, we generated a reference series for both the $P$. polysora and $P$. sorghi assays to determine the curves, $\mathrm{C}_{\mathrm{T}}$ values, and fluorescence range for a representative subsample. For each species, we assayed six representative samples: (i) two samples that exceeded the threshold during early cycles, (ii) two samples that exceeded the threshold in middle cycles, and (iii) two samples that exceeded the threshold during late cycles. The results of the Cepheid SmartCycler reactions performed with these samples are shown in Supplementary Figure S3. P. polysora samples analyzed using the PPOLY probe reached the threshold value of 30 between cycles 18 and 32, with fluorescence peaking at 110 to 150 units. $P$. sorghi samples analyzed using the PSORG probe reached the threshold value of 30 between cycles 23 and 32, with fluorescence peaking at 100 to 170 units. Data from these experiments plotted along with the PPOLY and PSORG standard curves are shown in Supplementary Figure S1. 


\section{Discussion}

In this work, our objective was to develop a real-time PCR assay based on the rDNA ITS sequence that would be capable of reliably discriminating between $P$. polysora and $P$. sorghi, two morphologically similar corn rust fungi that are responsible for quite distinct disease pathologies. The ITS has long been the region of choice for initial DNA sequence analyses of understudied organisms, and is facilitated in the genus Puccinia by the availability of rust-specific PCR primers (25). Although in some fungal groups the ITS sequence may be an unreliable marker for species differentiation because of low levels of variation or the presence of nonorthologous copies $(9,28)$, for the rust fungi, the ITS has been shown to possess utility for sequence and real-time PCR based applications $(15,19,26,31,45)$. With $14 \mathrm{bp}$ differentiating $P$. polysora and $P$. sorghi in the ITS 1 probe sequence, the assay developed in the present study provided an accurate, sensitive, and easily implemented protocol that could be performed from DNA in $30 \mathrm{~min}$. Altogether, analysis of the 26 recently collected U.S. samples of corn rust through real-time PCR using the PPOLY and PSORG probes unambiguously identified $100 \%$ of the samples as either $P$. polysora or $P$. sorghi . For $92 \%$ of the samples, molecular diagnosis corresponded with field identifications. For two samples-G10-928 and G10-929 - the molecular diagnosis (P. sorghi) conflicted with submission data ( $P$. polysora). The original field identification of G10928 and G10-929 was made by diagnostic clinic personnel as $P$. polysora based on the morphological assessment of transparent adhesive-tape-mounted urediniospores (C. Bradley, personal communication). The original samples of G10-928 and G10-929 no longer exist; therefore, it was not possible to reexamine these specimens. Given the unreliability of urediniospore-based species identification $(5,12)$ and the molecular results generated by the PPOLY/SORG assay from these and other samples collected globally over the course of 122 years (Fig. 3), we conclude that these samples are $P$. sorghi, not $P$. polysora. Importantly, this example demonstrates that, for the corn rust fungi, in the absence of teliospores, a morphology-based diagnosis may not provide sufficient evidence to support unambiguous identification of the pathogen.

An unanticipated outcome of this study was the ability of the PPOLY and PSORG probes to provide good-quality DNA-based confirmation of species identities from corn rusts preserved as herbarium materials. The herbarium specimens sampled in this study were originally collected between 1888 and 2006 from across the southern United States, Asia, Africa, and South and Central America (Table 1). Although the DNA derived from herbarium samples was degraded, real-time PCR reactions performed using the PPOLY and PSORG assays produced sufficient amplicon to provide a diagnosis for $87 \%$ of the herbarium samples (Fig 3; Supplementary Figure S2). Of the 27 specimens evaluated using the PPOLY/PSORG assay, all but one species identification corresponded with the species determination provided by herbarium curators. Reexamination of specimen MIN495555, curated as $P$. sorghi but with a molecular diagnosis of $P$. polysora, showed that the specimen possessed several features consistent with the morphology of $P$. polysora, most notably the telia. Because MIN495555 was collected in 1916, decades before the association of $P$. polysora with corn by Cummins (10), it is likely that the application of the $P$. sorghi name to this specimen is an artifact of the pre-1941 nomenclature. The successful implementation of the PPOLY and PSORG probes using herbarium DNA shows the potential for the application of real-time PCR diagnostics in the field of fungal taxonomy, providing scientists with a robust tool to develop connections between modern living samples characterized through DNA analysis and important type specimens known only through their morphological structures. In the present work, we were able to provide a connection between the DNA of modern $P$. polysora and a herbarium specimen of historical significance: the original Peruvian corn rust sample collected by Stakman in 1940 that provided the first indication that $P$. polysora was a pathogen of corn (BPI093821A; 10).
The basis of periodicity of SCR outbreaks in the United States continues to be one of the most compelling questions in this pathosystem. Given the fact that most corn hybrids grown in the United States are susceptible to the fungus (23), why is the disease not more common? Multiple races of the fungus are observed in tropical corn-growing regions $(6,34,41)$ south of North America that could conceivably move into U.S. corn acreage through aerial transport, particularly given the changing land use dynamics observed during the past 20 years (43). Our results also raise the question of whether there is also a greater level of molecular variability among non-U.S. populations of southern corn rust fungi that have been presumed to be $P$. polysora based on their morphological similarity, because four samples collected between 1943 and 1957 in South America and the Philippines could not be identified as either $P$. polysora or $P$. sorghi using real-time PCR. Our development of a diagnostic assay capable of detecting the presence of $P$. polysora from only small quantities of DNA will enable future research of SCR in the United States and could form the basis of informative epidemiological, biogeographic, or environmental studies of the fungus designed to address these questions. In particular, the demonstrated sensitivity of the PPOLY and PSORG probes will facilitate research where the fungus is present in only small quantities, or is not causing disease symptoms, such as rainwater monitoring analyses, surveys of asymptomatic corn tissue, or examination of alternate grass hosts such as eastern gamagrass.

\section{Acknowledgments}

We thank K. P. Nguyen, J. Kaufman, and B. Elliott for technical assistance; C. Harmon and the University of Florida Plant Disease Clinic for providing DNA extractions from field collected samples; D. McLaughlin and the Bell Herbarium and the United States National Fungus Collection Herbarium for sharing herbarium specimens; and the following individuals for sharing rust samples: G. Bergstrom, C. Bradley, D. Hershman, C. Hollier, S. Hulbert, Y. Jin, J. Johnson, B. Kemerait, S. Monfort, A. Roelfs, and P. Vincelli.

\section{Literature Cited}

1. Anikster, Y., Szabo, L.J., Eilam, T., Manisterski, J., Koike, S. T., and Bushnell, W. R. 2004. Morphology, life cycle biology, and DNA sequence analysis of rust fungi on garlic and chives from California. Phytopathology 94:569-577.

2. Barnes, C. W., and Szabo, L. J. 2007. Detection and identification of four common rust pathogens of cereals and grasses using real-time polymerase chain reaction. Phytopathology 97:717-727.

3. Barnes, C. W., Szabo, L. J., and Bowersox, V. C. 2009. Identifying and quantifying Phakopsora pachyrhizi spores in rain. Phytopathology 99:328338.

4. Cammack, R. H. 1958. Studies on Puccinia polysora Underw. I. The world distribution of forms of P. polysora. Trans. Br. Mycol. Soc. 41:89-94

5. Cammack, R. H. 1959. Studies on Puccinia polysora Underw. II. Description and life cycle of $P$. polysora in West Africa. Trans. Br. Mycol. Soc. 42:55-58

6. Carlos, C. R., and Ferreira, A. S. 2002. Variability in isolates of Puccinia polysora in Brazil. Fitopatol. Bras. 27:414-416.

7. Chavez-Medina, J. A., and Leyva-Lopez, N. E. 2007. Resistance to Puccinia polysora in maize accessions. Plant Dis. 91:1489-1495.

8. Chen, C. X., Wang, Z. L., Yang. D. E., Ye, C. J., Zhao, Y. B., Jin, D. M., Weng, M. L., and Wang, B. 2004. Molecular tagging and genetic mapping of the disease resistance gene $\operatorname{Rpp} Q$ to southern corn rust. Theor. Appl. Genet. 108:945-950.

9. Crouch, J. A., Clarke, B. B., and Hillman, B. I. 2009. What is the value of ITS sequence data in Colletotrichum systematics and species diagnosis? A case study using the falcate-spored, graminicolous Colletotrichum group. Mycologia 101:648-656.

10. Cummins, G. B. 1941. Identity and distribution of three corn rusts. Phytopathology 31:856-857.

11. Cummins, G. B. 1952. Uredinales from various regions. Bull. Torrey Bot Club 79:212-234

12. Cummins, G. B. 1971. The Rust Fungi of Cereals, Grasses and Bamboos. Springer-Verlag, New York.

13. Deadman, M. L., Sa'di, A. A., Maqbali, Y. A., Livingston, S., and Aime, M. C. 2006. First report of Puccinia sorghi on maize in Oman. Plant Dis 90:826.

14. Farr, D.F., and Rossman, A. Y. 2010. Fungal Databases, Systematic Mycology and Microbiology Laboratory. U. S. Dep. Agric. Agric. Res. Serv. http://nt.ars-grin.gov/fungaldatabases/

15. Frederick, R. D., Snyder, C. L., Peterson, G. L., and Bonde, M. R. 2002. Polymerase chain reaction assays for the detection and discrimination of the 
soybean rust pathogens Phakopsora pachyrhizi and P. meibomiae. Phytopathology 92:217-227.

16. Futrell, M. C. 1975. Puccinia polyspora epidemics on maize associated with cropping practice and genetic homogeneity. Phytopathology 65:1040-1042.

17. Futrell, M. C., Hooker, A. L., and Scott, G. E. 1975. Resistance in maize to corn rust, controlled by a single dominant gene. Crop Sci. 15:597-599.

18. Glynn, N. C., Dixon, L. J., Castlebury, L. A., Szabo, L. J., and Comstock, J. C. 2010. PCR assays for the sugarcane rust pathogens Puccinia kuehnii and P. melanocephala and detection of a SNP associated with geographic distribution in P. kuehnii. Plant Pathol. 59:703-711.

19. Hernández, J. R., Palm, M. E., and Castlebury, L. A. 2002. Puccinia hemerocallidis, cause of daylily rust, a newly introduced disease in the Americas. Plant Dis. 86:1194-1198.

20. Holway, E. W. D. 1897. Mexican fungi. Bot. Gaz. 24:23-38.

21. Hulbert, S. H., and Bennetzen, J. L. 1991. Recombination at the Prl locus of maize. Mol. Gen. Genet. 226:377-382.

22. Jin, Y., Szabo, L. J., and Carson, M. 2010. Century-old mystery of Puccinia striiformis life history solved with the identification of Berberis as an alternate host. Phytopathology 100:432-435.

23. Jines, M. P, Balint-Kurti, P., Robertson-Hoyt, L. A., Molnar, T., Holland, J. B., and Goodman, M. M. 2007. Mapping resistance to southern rust in a tropical by temperate maize recombinant inbred topcross population. Theor. Appl. Genet. 114:659-667.

24. King, S. B., and Scott, G. E. 1982. Development of southern rust on maize at different stages of maturity. Plant Dis. 66:477-481.

25. Kropp, B. R., Albee, S., Flint, K. M., Zambino, P., Szabo, L. J., and Thomson, S. V. 1995. Early detection of systemic rust infections of dyers woad (Isatis tinctoria) using the polymerase chain reaction. Weed Sci. 43:467-72.

26. Kropp, B. R., Hansen, D. R., Wolf, P. G., Flint, K. M., and Thomson, S. V. 1997. A study on the phylogeny of the dyer's woad rust fungus and other species of Puccinia from crucifers. Phytopathology 87:565-571.

27. Leonard, K. J. 1974. Foliar pathogens of corn in North Carolina. Plant Dis. Rep. 58:532-534

28. O'Donnell K., and Cigelnik E. 1997. Two divergent intragenomic rDNA ITS2 types within a monophyletic lineage of the fungus Fusarium are nonorthologous. Mol. Phylogenet. Evol. 7:103-116.

29. Pavgi, M. S. 1972. Morphology and taxonomy of the Puccinia species on corn and sorghum. Mycopathol. Mycol. Appl. 47:207-220.
30. Pavgi, M. S., and Flangas, A. L. 1959. Occurrence of southern corn rust in Wisconsin. Plant Dis. Rep. 43:1239-1240.

31. Pedley, K. F. 2009. PCR-based assays for the detection of Puccinia horiana on chrysanthemums. Plant Dis. 93:1252-1258.

32. Raid, R. N., Pennypacker, S. P., and Stevenson, R. E. 1988. Characterization of Puccinia polysora epidemics in Pennsylvania and Maryland. Phytopathology 78:579-585.

33. Rhind, D., Waterston, J. M., and Dighton, F. C. 1952. Occurrence of Puccinia polysora Underw. in West Africa. Nature 169:631.

34. Robert, A. I. 1962. Host range and races of the corn rusts. Phytopathology 52:1010-1015.

35. Rodriguez-Ardon, R., Scott, G. E., and King, S. B. 1980. Maize yield losses caused by Southern corn rust. Crop Sci.20:812-814.

36. Ryland A. K., and Storey, H. H. 1955. Physiological races of Puccinia polysora Underw. Nature 176:655-656.

37. Schall, R. A., McCain, J. W., and Hennen, J. F. 1983. Distribution of Puccinia polysora in Indiana and the absence of cool weather form as determined by comparison with $P$. sorghi. Plant Dis. 67:767-770.

38. Scott, G. E., King, S. B., and Armour, J. W., Jr. 1984. Inheritance of resistance to southern corn rust in maize populations. Crop Sci. 24:265-267.

39. Sims, T., IV. 1980. Southern rust of corn recognized in Kansas. Plant Dis. 64:500

40. Thompson, J. D., Higgins, D. G., and Gibson, T. J. 1994. CLUSTAL W: Improving the sensitivity of progressive multiple sequence alignment through sequence weighting, position-specific gap penalties, and matrix choice. Nucleic Acids Res. 22:4673-4680.

41. Ullstrup, A. J. 1965. Inheritance and linkage of a gene determining resistance in maize to an American race of Puccinia polysora. Phytopathology $55: 425-428$.

42. Underwood, L M. 1897. Some new fungi, chiefly from Alabama. Bull Torrey Bot. Club 24:81-86.

43. Vincelli, P. 2010. NPDN giving increasing attention to southern corn rust. Nat. Plant Diagn. Network News 6:1-2.

44. Widstrom, N. W., and Young, J. R. 1980. Double cropping corn on the coastal plain of the southeastern United States. Agron. J. 72:302-305.

45. Zambino, P. J., and Szabo, L. J. 1993. Phylogenetic relationships of selected cereal and grass rusts based on rDNA sequence analysis. Mycologia $85: 401-414$. 